\title{
Selected Reference Books of 1997
}

\section{Eileen Mcllvaine}

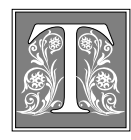

his article follows the pattern set by the semiannual series initiated by the late Constance M. Winchell more than fifty years ago and continued by Eugene Sheehy. Because the purpose of the list is to present a selection of recent scholarly and general works, it does not pretend to be either well balanced or comprehensive. A brief roundup of new editions of standard works is provided at the end of the articles. Code numbers (such as AJ51) have been used to refer to titles in the Guide to Reference Books, 11 th ed. (Chicago: ALA, 1996).

\section{Book Reviews}

Internationale Bibliographie der Rezensionen wissenschaftlicher Literatur (International Bibliography of Book Reviews of Scholarly Literature), 1985-1994. CD-ROM. Osnabrück, Germany: F. Dietrich, 1997. \$1300. To be annual.

The retroprospective CD-ROM, to be supplemented annually, is a cumulation of volume 15 through volume 24 , part 2 , 1985-1994, of the printed version, usually abbreviated IBR (AA373). Librarians on a first name basis with the printed version know its virtues and its frustrations. On the plus side, it indexes book reviews in several thousand scholarly journals in all Western languages and in all subjects; on the minus side, its semiannual publi- cation schedule and cumbersome arrangement usually made it a source of last resort.

The virtues of the print source are all retained in the CD-ROM version, and few, if any, of its drawbacks. A manual accompanies the CD-ROM, which I was not able to see; even without it, the index is very easy to use, especially for anyone familiar with the America: History and Life or Historical Abstracts CD-ROMS.

The index can be searched by any or all of several categories: broad subject, subject headings (in English), author, title (really keyword in title), journal, date, or reviewer. The only slightly confusing aspect is the protocol for names. Last name, first name, the logical sequence, really searches last name or first name. The context-sensitive help screens explain that "last name, first name" (within quotation marks) or last name.first name (names separated by a period) is the proper way to search for authors or reviewers. The displays are quite clear, though each review is listed as a separate entry. The address of the journal is given, making identification much easier.

With luck, the updates will appear in a timely fashion, but even this retrospective disc allows libraries easy access to scholarly reviews in non-English languages, access previously available only through specialized indexes or through

Eileen McIlvaine is Head of Reference and Collections in Butler Library at Columbia University; e-mail: mcilvain@columbia.edu. Although it appears under a byline, this list is a project of the reference departments of Columbia University Libraries and notes are signed with the initials of one of the following staff members: James Coen, Business Library; Mary Cargill, Anice Mills, Robert H Scott, Junko Stuveras, Sarah Spurgin Witte, Butler Library; Olha della Cava, Lehman Library; Nancy Friedland, Undergraduate Library. 
the ISI databases with their odd citations and incomplete author names. This will be an indispensable reference tool for all academic libraries.-M. C.

\section{Proverbs}

Cordry, Harold V. The Multicultural Dictionary of Proverbs: Over 20,000 Adages from More Than 120 Languages, Nationalities \& Ethnic Groups. Jefferson, N.C.: McFarland, 1997. 406p. \$47.50 (IBN 07864-0251-2). LC 96-33264.

The 20,000 entries in this international "compendium of proverbial wisdom " (Pref.) are arranged by topic to "facilitate comparison" among the various languages and cultures included. Entries are then listed alphabetically by first word, with the name of the language or ethnic group from which it comes given in parenthesis. Cross-references to related topics refer the user, for example, from "law" to "injustice," "lawsuits," "lawyers," and "loopholes."

"A number of proverbs found in literature ... were not recorded if earlier appearances were discovered"; however, proverbs appearing in the works of Shakespeare, Cervantes and other major authors are cited at the end of the entry, even when similar proverbs exist in Greek or Latin. A valuable source index allows one to see the number of proverbs attributed to individual authors whereas a subject index with cross-references helps access topics. A keyword index is only partially successful: indexing keywords such as "good" or "like" results in columns and columns of entry numbers, making the index virtually useless. A more practical access point would have been an index to the language or ethnic group cited. That would have allowed a reader to find, for example, all the Russian proverbs. As it is, there is no indication of how many proverbs come from which language, nationality, or ethnic group.

Another confusion is the peculiar bibliography, arranged chronologically, with no place of publication or name of pub- lisher included. No explanation for this lack of completeness is given. The selections themselves can make one overlook the quirks of the bibliography; the range of proverbs indicates the depth of research. The section on marriage, for example, is particularly rich in comparing different cultures' views on the subject.

This collection is similar in form and content to the Prentice-Hall Encyclopedia of World Proverbs by Wolfgang Mieder, published in 1986 (BE157). Although Mieder's volume does not include a source index, his bibliography is more comprehensive and better organized than Cordry's.

Despite its flaws, the Multicultural Dictionary of Proverbs should prove to be a valuable and entertaining reference source for cultural anthropologists, linguists, and anyone who studies the human condition.-A. M.

\section{Literature}

Autoras en la Historia del Teatro Español, 15001994. Ed. Juan Antonio Hormigón. Madrid: ADE, 1997. 2 vols. Teoria y Practica del Teatro, 10-11. 4900 pts. (ISBN 84-87591-57-4). LC 96-17193. Contents: vol. 1, Siglos XVII-XVIII-XIX; vol. 2, Siglo XX (1900-1975).

Women playwrights of Spain from the sixteenth century to 1975 are the subject of this extensive bio-bibliography. The reference work is accompanied by an introductory essay, an alphabetical index by author which covers both volumes, and a bibliography of catalogs, indexes, and bibliographies (pp. 381-87).

The main section is divided by time period and then by playwright. Each subdivision by time period is preceded by an essay that gives an overview of the period. A typical entry under author gives a concise biography, an overview of her works, and entries for individual works which might include title, imprint (or manuscript) data, date and place of performance, genre, scene(s), dramatis personae, plot outline, and comments. Some entries also have a bibliography of manu- 
scripts, catalogs, and critical works relating to the play. At the end of the second volume are the biographical notes on the collaborators, the index by title of the play, and a detailed table of contents.

This is an important tool for libraries serving Spanish literature and women's studies departments.- J. S.

\section{The Feminist Encyclopedia of German Litera-} ture. Ed. Friederike Eigler and Susanne Kord. Westport, Conn.: Greenwood, 1997. 676p. $\$ 99.50$ (ISBN 0-313-293139). LC 96-18204.

This is a compilation of brief articles by more than 100 contributors discussing and analyzing major topics relating to German literature from a feminist perspective. There are "relatively few separate entries on women authors . . . and even fewer for specific works" (Introd.) because a number of biographical dictionaries on German women writers are available. All the entries are signed and all include brief bibliographies.

The writing is academic in the current meaning of the word, which is to say often convoluted. For instance, the "low social standing of actors made patriarchal obstacles superfluous" ( $p .4)$ seems to mean actresses were often prostitutes. The intended audience is not really clear. There are some very basic definitions: "A maid servant is a woman who is employed in a household and who takes care of house-hold related tasks" (p. 295), or "A hymn is a song of praise" (p. 248), with some complicated summaries of contemporary literary theory and theorists. Many of the suggested sources are in German, making this more useful for graduate students than undergraduates. Libraries with large women's studies programs or active German departments may find this a useful source.-M. C.

Peterson, Bernard L. The African American Theatre Directory, 1816-1960: A Comprehensive Guide to Early Black Theatre Organizations, Companies, Theatres, and Performing Groups. Westport, Conn.: Greenwood, 1997. xxix, 301p. \$75 (ISBN 0-313-29537-9). LC 96-9534. The author, a noted name in the field of African American theater research, and a group of research consultants have produced a "comprehensive reference book that includes succinct information on some 500 pioneer African American theatrical organizations, companies, and performing groups plus more than 200 blackoriented ... performance spaces" (Pref.). The logical cutoff date is 1960 because the surge in black groups during that decade needs its own study. It is arranged alphabetically by company or theater; no individuals are included though there is a thorough name index.

Many of the entries are brief, and undocumented, presumably to save space. But it would be fascinating to know the sources of the information-the researchers must have combed through numerous newspapers and theatrical periodicals for these smaller groups, the lifespans of which, according to the Foreword, averaged five years. Additional sources are given for some of the more prominent groups, and there is a more general bibliography on black theater and a useful list of dissertations and journals.

The groups listed range from minstrel and vaudeville troupes to college theater groups, and any library supporting African American studies or American theater will want this impressive, pioneering work.-M. S.

\section{Archives}

ArchivesUSA: Integrated Collection and Repository Information [computer file]. Alexandria, Va.: Chadwyck-Healey, 1997. \$1,495/year. Available on CDRom and the Internet at http:// archives.chadwyck.com, with subscription.

NUCMC Z39.50 Gateway to the RLIN AMC File [computer file]. Washington, D.C.: Library of Congress, 1997. Free. Available on the Internet through the NUCMC 
homepage: http://lcweb.loc.gov/coll/ nucme/.

ArchivesUSA is available as a CD-ROM or via the Web. It contains the complete set of printed NUCMC volumes (DB34) through 1994, describing 72,300 collections from 1,406 repositories, as well as NUCMC tapes which are contributed by the Library of Congress to the RLIN AMC file on behalf of libraries that do not contribute their own records to RLIN AMC. It provides up-to-date addresses for all repositories listed in the Directory of Archives and Manuscript Repositories in the United States (1988. DB30). ArchivesUSA also acts as an online index to the United States portion of the National Inventory of Documentary Sources (NIDS), another Chadwyck-Healey product (AK112). NIDS reproduces on microfiche the finding aids of archives and manuscript collections throughout the United States and the United Kingdom. It is an invaluable resource, often providing file and item level access to archives and manuscript collections.

ArchivesUSA has NUCMC, NIDS, and some RLIN AMC subject headings. One of its strongest features is the excellent search engine, which allows searching by a combination of keywords, subject headings, repository names, repository cities, with the ability to browse virtually every category for appropriate headings, and, in some cases, to continue searching on subject headings from a retrieved record. It also includes the home page URLs, an especially useful feature of the Web version. The only problem is that it lacks the complete RLIN AMC file, a significant omission. Beginning in the mid-1980s, many research and university libraries cataloged their records in RLIN and often all new acquisitions and all updates were cataloged only in RLIN. Most of the items originally submitted to NUCMC also were recataloged to reflect the new standards for archival records. So most research institutions have their complete holdings in a more updated form than would be found in the older printed NUCMC volumes. The only RLIN records in ArchivesUSA are the records that the NUCMC team prepared on behalf of smaller libraries that do not contribute to RLIN on their own.

Using Columbia as an example, we have no collections in ArchivesUSA that were not also in RLIN, and the RLIN records tend to be more complete (with more subject headings); all recently acquired collections are only in RLIN and not in ArchivesUSA. Unfortunately, Columbia did not participate in the NIDS program, so RLIN will still be the best resource. Chadwyck-Healey provides a button on the Web site for libraries to contribute records for inclusion in subsequent editions of ArchivesUSA and is hoping that this will make the file more complete.

NUCMC Z39.50 Gateway_contains the full RLIN Archives and Manuscripts Cataloging, some 500,000 records, including cataloging contributed by the NUCMC team from about 1984 to the present, together with all the records contributed to RLIN by members. The RLIN AMC records describe collections in RLG libraries as well as those in smaller libraries surveyed in recent National Historical Records Survey projects. It is a huge file, and there are significant gaps. The holdings of the Newberry Library in Chicago, for instance, are not included in RLIN, and they are only available in the printed volumes of NUCMC and thus only available online from Chadwyck-Healey.

Librarians familiar with the RLIN AMC file will find the NUCMC on the Web more difficult to use because it does not allow limiting by location or internal truncation, but it is much easier than searching for AMC records in Eureka. Readers unfamiliar with RLIN commands probably will enjoy searching because it provides a variety of name, subject, and title search options. It is slow, perhaps because of high use, and times out after five minutes. But it is free! 
The Library of Congress NUCMC page also includes links to lists of archives and manuscript collections, information about the printed volumes, and other useful information.

ArchivesUSA is expensive, but it does provide access to records not in RLIN (as well as many records in RLIN) and it incorporates references to the NIDS finding aids. It is much easier to search; and the CD-ROM version provides the usual downloading and printing options. Readers will not have to deal with the frequent timeouts. Large research libraries will want to provide access to RLIN AMC as well as the ArchivesUSA database. Smaller libraries may choose only to provide access to RLIN AMC.

An international list of more than 2,300 sites is maintained at the University of Idaho by Terry Abraham: Repositories of Primary Sources, http:/ / www.uidaho.edu/special-collections/Other.Repositories.html. It is the most complete list of archives and manuscript sites on the Web. Its only weakness is a regional organization, with U.S. states and Canadian provinces grouped together geographically, with states sich as Iowa and Minnesota in the Eastern Division. Repositories are listed alphabetically by state within each division, with geographic indexes. The site also provides links to other lists and archives-related sites, and a submission form for additions and corrections.-S. S. W.

DeWitt, Donald L. Articles Describing Archives and Manuscript Collections in the United States. Westport, Conn.: Greenwood, 1997. 458p. Bibliographies and Indexes in Library and Information Science, 11. $\$ 89.50$ (ISBN 0-313-295980). LC 96-37042.

This annotated bibliography brings together articles published from 1890 to the present on aspects of U. S. archives and manuscript collections. It has a topical arrangement, describing collections in business, fine arts, literature, the military, religion, and politics; collections embrac- ing specific groups: women, ethnic minorities, professional organizations; and collections organized by region or type of material. Foreign repositories holding U.S. records, and U. S. repositories holding foreign records also are included. Indexes allow the reader to pinpoint specific repositories and collections. The annotations are informative and succinct, clearly the work of one gifted in writing archival descriptions. This volume is intended to serve as a companion to DeWitt's Guide to Archives and Manuscript Collections in the United States (1994. DB29) and is recommended for all reference departments supporting graduate or advanced undergraduate research.-S.S.W.

\section{Social Sciences}

Fast, Julius, and Timothy Fast. The Legal Atlas of the United States. New York: Facts on File, 1997. 200p. $23 \times 29 \mathrm{~cm}$. $\$ 80.00$ (ISBN 0-8160-3128-2). LC 975621.

The Fasts have compiled an atlas that "examines on a state-by-state basis, some of the types of law we believe most affect Americans, family law and personal law ... and the major classifications of crime" (Introd.). To this end, the authors present about 140 maps with explanatory text under broad headings. For example, under Family Law, one finds Blood Tests and Licenses, 1993; under Personal Law, Abortion Rates, 1988, Gambling Arrest Rates, 1991, Praying in School, 1993; under Corrections: Female Prisoners, 1993; or under Justice System: Racial Distribution of Lawyers, 1990.

Though the compilers intended to use 1990 as a base year, the period of coverage of the maps ranges from 1988 to 1993 with the source of each map cited in the Bibliography (pp. 189-95). The sources vary from the Information Please and World Almanacs (though the current volumes do not carry the tables ascribed to them), to personal correspondence with relevant associations, to Web sites, to government publications such as Statistical Abstracts 
and the Uniform Crime Reports from the Department of Justice.

The maps are clearly laid out; for most of them the color is used creatively and enhances the presentation. And the subject index is quite helpful. But one wonders just how useful students will find a compilation of almost ten-year-old materials because much has changed. It definitely will be seen as background information with more recent statistical resources needed for comparison or updating. Perhaps the publishers contemplate another atlas soon after the next census.E. M.

Notess, Greg R. Government Information on the Internet. Lanham, Md.: Bernan Pr., 1997. Various paging. (ISBN 089059-081-8). LC 97-197226.

Government Information on the Internet is an invaluable resource for both librarian and researcher. It contains a wealth of information, is well organized, and is amply indexed. Admittedly, this is only a snapshot in time-Web site information is notoriously volatile. However, knowing that a resource was once available on the Internet means that it is likely to still exist and, with a bit of effort, can be located. Hence, the rationale for a print directory of online information.

As to content, more than 1,200 governmental Internet resources are described, giving the sponsoring agency, primary and alternative access routes, a description of the contents, and a list of assigned subject headings. Though the primary focus is on U.S. federal government Web resources, there is selective coverage of state government, international, intergovernmental, and foreign-country Web sites. The directory is organized into sixteen subject-oriented chapters (agriculture, census and other statistics, environment, education, military, etc.), preceded by an introduction that both explains to the noninitiate the characteristics of the information included and sets out the parameters followed by the compiler. Each chapter, after a brief introduction, is further broken down into a listing of general and specialized sites within the subject area. Furthermore, and this librarians will particularly appreciate, there is an emphasis on publications available at sites and the SuDoc Numbers when available, are indicated. Another valuable contribution is the notice within each chapter of featured sites, i.e., centralized subject finding aids or one-stop shopping sites, such as the Federal Web Locator, U.S. Business Advisor, Online Educational Resources, etc. These are excellent starting points in the quest for relevant government information. Separate indexes exist for: Primary and Alternative Access URLs, SuDoc Numbers, Publication Title, Agency/Acronym/Title, and subject.

With over one million Web pages in the gov domain alone, the compiler is to be commended for imposing a degree of order, no matter how arbitrary or tentative, on what to many librarians and researchers is pure chaos.-O. $\mathrm{dC}$.

\section{Women's Studies}

Encyclopédie politique et historique des femmes: Europe, Amérique du Nord. Ed. Christine Fauré. Paris: Presses Universitaires de France, 1997. 885p. Fr 498. (ISBN 213048316X). LC 97169490.

This international work on women in political and historical contexts from early modern Europe to contemporary Europe and North America is more a collection of essays in spite of the title "encyclopédie." Divided into three groups, the first is concerned with early modern discourses on women's ability to govern: the Salic law; viewpoints of Luther, Calvin, and Bodin; women of the Fronde; and women in the writings of Hobbes and Locke. The second group of essays examines the roles of women in revolutions: French, English, Russian, as well as nineteenth-century Greece and the Netherlands. The third group deals with mid-nineteenth- to 
twentieth-century struggles for democracy, which includes such varied topics as women's political participation, their roles in fascist Italy, the Third Reich, Vichy France, Spain under Franco, Salazarian Portugal, women and Islam in the West, Turkish immigrant women, participation in parliamentary politics (with a color map of the world), and the role of international organizations in promoting equality.

Each article is accompanied by a bibliography of primary and secondary sources. A personal name index and biographical notes on some forty contributors complete the encyclopedia. Recommended for university libraries.-J. S.

\section{History and Area Studies}

Jankovi..., Vendeli $1 / 2$, and Anna

Òkorupová. Bibliografia $k$ dejinám

Slovenska: literatúra vydaná do roku 1965.

Bratislava: AEP, 1997. 781p. LC 97147952.

Arguably one of the lesser-known lands of Europe (at least in this country) is Slovakia, a small nation situated in the Carpathian Mountains and along the north bank of the Danube River, between Poland to the north and Hungary to the south, the Czech Republic and Austria to the west, and the Ukraine to the east. Its central location and its recent emergence as an independent state seem destined, however, to thrust it into the spotlight in the near future, particularly given its exclusion from the list of East European candidates for membership in NATO, turning it into a long corridor extending deep into the territory of the Western alliance.

Certainly, one of the reasons for our poor understanding of the country to date is its complex history, most of it spent as a component of some larger political unit. This land first appears on the historical scene in the ninth century as part of Great Moravia, one of the earliest important Slavic states, then as part of the lands of the Hungarian Crown from the eleventh to early twentieth centuries, then as the junior partner in interwar Czechoslovakia, then a brief troubled interlude as a puppet state of the Axis, followed by nearly half a century as part of Czechoslovakia, until finally achieving the status of a sovereign state in 1993. However, scholars interested in gaining a better sense of that history also have been hampered by the absence of a retrospective bibliographic compilation of the historical literature, particularly acute in the case of a country whose historiography has been written in so many different languages.

This volume represents an important step toward addressing that problem. The culmination of a project begun by the Institute of History of the Slovak Academy of Sciences in 1962, it contains some 18,000 citations to books and articles in Slovak, Czech, Hungarian, German, Polish, and other languages, covering the history of Slovakia (and the states of which it was a part) from the earliest times to 1965 (although, because it also appears to include no works published after 1965, the period of subject coverage is actually somewhat shorter). No doubt because of the period in which it was compiled, there appears to be far less emphasis on works published outside the Eastern bloc, although there are certainly many citations of that literature as well. (Incidentally, there appears to be even fewer citations of literature in Russian.) There also is no coverage of the extensive Slovak emigration.

The work is divided into two main parts, a general section including coverage of general historiographic and methodological issues, auxiliary sciences, collections of sources, historical geography, and surveys of Central European, Slavic, Hungarian, Czechoslovak, and Slovak history. The second part is divided into eleven chronological sections, each of which is further subdivided by field and topic. Unfortunately, within each section, entries are arranged either chronologically by period of coverage or alphabetically by person or place, with no section 
subheadings, making the browsing of individual sections very difficult. One must have recourse to the index of authors and subjects, which is thankfully fairly detailed. The table of contents, section headings, and introductory material are in English as well, although the English portions cry out for a native-language editor; at certain points the text is utterly incomprehensible.

As the last comments suggest, this work has some serious flaws but is nonetheless an important addition to the tools for advanced research in East European history. Any collection supporting this type of work will need to acquire this title.-R. H. S.

McCauley, Martin. Who's Who in Russia Since 1900. London, New York: Routledge, 1997. 268p. \$75 (ISBN 041513897-3). LC 96-42009.

This latest in Routledge's series of short biographical handbooks, compiled and written by Martin McCauley, provides a handy desktop guide, particularly for the novice or intermediate user, of the key personalities of Russian politics and society in the twentieth century. Three hundred or so brief but pithy entries profile figures in a variety of fields. Although literature and politics are the dominant ones, prominent scientists, academicians, economists and business figures, athletes, entertainers, cosmonauts, chess masters, musicians, artists, and others are featured as well. Naturally, in a book of this length, only the leading figures can be represented, but given that preimposed limitation, the author has done a good job of compiling a relatively comprehensive list. The sketches are drawn in a lively, opinionated manner that, at its best, is a refreshing change of pace but, at its worst, can be a little flip. As one might also expect in a short work of this type, bibliographic citations are not provided with the entries. However, the book could have profited from an index or from more explicit cross-referencing: For example, readers might want to find the biographies of all the chiefs of the organs of state security and the text, as written, does not support that kind of linkage. One really has to know a name to pick out an entry. In any case, this book clearly will serve as a valuable compendium for anyone seeking a desktop guide to the key personalities of modern Russian history and society, or to any basic reference collection. Moreover, although it is not likely to bump any earlier titles from the shelf in a more advanced reference collection, its timeliness, comprehensive perspective, and fresh style should make it a welcome addition there as well.-R. H. S.

McKinstry, E. Richard. Personal Accounts of Events, Travels, and Everyday Life in America: An Annotated Bibliography. Winterthur, Del.: Henry Francis duPont Winterthur Museum, 1997. 236p. \$40 (ISBN 0-912724-39-0). LC 9710832.

Personal Accounts of Events, Travels, and Everyday Life in America is an engaging and informative work. The third in a series of bibliographies published to describe the holdings of the Winterthur Library, this volume focuses on the personal accounts, diaries, and travel narratives held in the Joseph Downs Collection of Manuscripts and Printed Ephemera.

The catalog includes an annotated bibliography of the manuscript collection, a listing of 406 published travel narratives held in the Printed Book and Periodical Collection at Winterthur, and indexes to each section. The main body of the catalog includes an expertly annotated bibliography detailing ninety-four manuscript collections which represent an insider's view of American society at large. The diaries and travel narratives listed here are written by a varied population (not necessarily ethnic) of merchants, artists, publishers, children, and young adults, among others. The subjects of the entries are diverse, written records of the daily occurrences and ob- 
servations in the lives of ordinary people, narratives of travel by sea and land to such places as Havana, and accounts of the Civil War and its consequences.

Entries span from 1762 through 1938, with the majority of holdings written during the nineteenth century. The works range in size from fewer than fifty pages to multivolume works; some capture an afternoon and others represent a significant part of the diarist's life. An entry includes the name of the diarist; birth and death dates, when available; size of the collection; and years written. The annotations detail the contents of the collections and are enriched by quotations from the manuscripts with biographical material culled from such sources as the Dictionary of American Biography (AH62), Who Was Who in American Art (BF153), and historical contexts and references obtained from sources as the Encyclopedia of American History (DB44). When available, the annotations are followed by reference to works about or related to the diarist. In fact, the reader is encouraged to "separate the contents into two parts: primary material that reveals themes, and secondary materials that provide a background and context to what is judged important" $(p . x x)$. This format is instructive and inviting, and provides a wealth of information for the reader.

A detailed subject index is provided. In addition, a chronological index to the manuscripts is provided, useful for identifying a manuscript written during a specific event, for example, the Civil War.

Although the heart of the work remains the annotated bibliography, the second part includes a bibliography of published travel narratives held by the Winterthur Library. These entries are not annotated and are expected to be widely available. A short-title bibliography lists works such as Evan's American Bibliography (AA405) for further reference. A geographic index to the published travel accounts also is provided.
This work is a strong addition to collections holding Matthew's American Diaries (BE507n) and the expanded and revised edition of American Diaries (BE507). It is highly recommended for collections supporting a curriculum in American history or American studies.-N. F.

Vogel, Joseph. The Encyclopedia of Precolonial Africa: Archaeology, History, Languages, Cultures, and Environments. Walnut Creek, Calif.: AltaMira Pr., 1997. 605p. \$124.95 (ISBN 0-7619-89021). LC 96-51227.

This work seems somewhat mistitled. Although it does deal to some extent with the continent as a whole and to some cursory extent with the history of recent centuries, "Encyclopedia of Sub-Saharan African Prehistory" might be a more appropriate designation because this is where the real focus lies. Given that caveat, however, the work appears to do an admirable job of synthesizing the oftendiverse research in these areas for a reader capable of handling a fairly technical text.

Edited by anthropologist and archeologist Joseph O. Vogel, the Encyclopedia brings together the work of about 80 specialists from Africa, Europe, and the United States. The text, consisting of survey essays rather than brief articles for ready reference, is divided into five sections: "African Environments," dealing with issues of geology, climate, vegetation, and disease; "Histories of Research," providing a useful look at the evolution of studies in this field; "Technology," describing in moderately technical terms techniques of stoneworking, pottery manufacture, metallurgy, and architectures encountered in the region; "People and Culture," which includes an overview of the historical development of the sub-Saharan languages, and discussions of the characteristic patterns of life in the region-foraging, pastoralism, and farming-and a brief look at topics in ethnoarchaeology; and the longest single section, "Prehistory of Africa," with ex- 
tensive discussions of the emergence of the human species, mankind's early life on the continent, the period of advanced foraging, rock art, the ceramic late stone age, beginnings of food production, iron age, social complexity, trade and commerce, historical archeology. The articles are followed by bibliographies of key literature, and an extensive index enhances access to the text. One slight disappointment here is the very brief coverage accorded to the well-known history of the precolonial states of the region, particularly those of West Africa and Ethiopia.

This will be a difficult work for beginners but seems an essential acquisition for any collection attempting to offer advanced coverage of African history.R. H. S.

\section{Sciences}

Glut, Donald F. Dinosaurs: the Encyclopedia. Jefferson, N.C.: McFarland, 1997. 1,076p. \$145 (ISBN 0-8995-0917-7). LC 95-47668.

From the movies to stuffed animals, dinosaurs have enjoyed great popularity in recent years. A quick search in Books in Print retrieved 2,775 entries for dinosaurs, of which 1,816 items were in the juvenile literature category. This encyclopedia was edited by the author of two previous reference books on the same subject (Dinosaur Dictionary, 1972, and Complete Dinosaur Dictionary, 1992, previously published in 1982 as the New Dinosaur Dictionary). The editor affirms that this edition is "far more detailed, complete and technical than either of those previous books ever attempted to be" (Pref.) The work is aimed at specialists, students of paleontology, and serious amateurs. It synthesizes the basic information and writing of paleontologists on the subjects.

Throughout the book, articles are well documented and provide reference to original scholarly monographs and journal articles which are listed in the Bibliography (pp. 1023-1057). There are numerous black-and-white photographs, line drawings, and pictures of reconstructed habitats of the extinct species. The editor notes that those illustrations are done by reputable artists based on known factual evidence.

The book is divided into five sections: background, dinosaurian systematics, the dinosaurian genera, nomina nuda, and excluded genera. The background section discusses the origins of dinosaurs, their relationships to birds, warm-blooded and cold-blooded dinosaurs, and the longstanding debate on the causes of dinosaur extinction. The main part of the book is the section on dinosaurian genera. Every authentic generic name is arranged alphabetically. Each entry typically contains a complete name, name derivation, type of species, occurrence, age, known material, diagnosis of genre, and comments. The volume ends with a bibliography, glossary, and index.

The encyclopedia is not quite the kind of thing you would hand to grade-school pupils, but it is a useful addition to college and university libraries.- J. S.

\section{New Editions and Supplements}

The first volume of the Random House Historical Dictionary of Slang in 1994, edited and compiled by J. E. Lighter (New York: Random House, 1994; 1,006p.), was published to uniformly good reviews. Now volume 2 has appeared covering letters H-O (1997; 736p. \$65). Here, too, are fascinating entries with good examples and definitions but little in the way of derivation or context. The Bibliography consists of five additions to the bibliography in volume 1. The Guide to the Dictionary, the Pronunciation Key, and the List of Abbreviations are reprinted from volume 1 , which is a help for the user.

ITA, the Internationale Titelabkurzungen von Zeitschriften; International Title Abbreviations of Periodicals, Newspapers, Important Handbooks, Dictionaries, Laws, Institutions, compiled by Otto Leistner $\left(7^{\text {th }} \mathrm{ed}\right.$. Osnabrück: F. Dietrich, 1997; 3 vols. [2,371p.] 890DM; $4^{\text {th }}$ ed. 1990 AD22) con- 
tinues to grow. This edition adds "about 10,000 abbreviations and numerous formerly recorded abbreviations have been updated" ( $p$. vii).

Would you not think that Oxford University Press, with a databank of new quotations and a proven record with the Oxford Dictionary of Quotations, compiled by Angela Partington (BE113), could give a bibliographic citation in a quotation dictionary that would include at least a page number for the source? It is a help to know the quotations are verified, but to be told they are in a particular novel or play with no further guidance can be frustrating. That is the case with their two new quotation dictionaries. The Oxford Dictionary of Phrases, Sayings, and Quotations by Elizabeth Knowles (1997; 694p. £31.33; \$39.95) arranges the text by theme, Absence to Youth, with a keyword index. For each entry, a context is given, and an author and title. No author approach is provided. A quick check of the quotations shows overlap with the Oxford Dictionary of Quotations: of twelve quotations under the term politicians, ten are in the Partington, of twelve under life, eleven are in the older work. Of twelve randomly chosen phrases in the Knowles, eight appear in Brewers Dictionary of Phrase and Fable (AC91). The Oxford Dictionary of Literary Quotations, edited by Peter Kemp (1997; 479 p. $£ 28.68, \$ 37.50)$, arranges its quotations in two sections: "The Writer's World" (by theme) and "Writers and Their Works" (by writer's name). The indexes are for author and keyword. One must hope that the editors of the Oxford Dictionary of Quotations will continue to have a scholarly attitude toward a reference work.

B. C. Bloomfield, as chair of the Rare Books Group of the Library Association in London, is responsible for the work of sending questionnaires and follow-ups (and occasionally visits) and of editing the responses in order to compile a second edition of the Directory of Rare Book and Special Collections in the United Kingdom and the Republic of Ireland (London: Library Association, 1997; 740p. £98; 1st ed. 1985. AK143). Still geographically arranged, an entry can be quite extensive comprising address, description of holdings, list of finding aids unpublished and published. The index offers some subject access along with names. Personal libraries have been removed in this edition.

David M. Scholer compiled the Nag Hammadi Bibliography 1948-1969 (Leiden: Brill, 1971; 201p.) for works written on the site as well as books and articles on the texts discovered there. The annual supplementary bibliographies by Scholer which followed in Novum Testamentum have been cumulated and published in Nag Hammadi Bibliography 1970-1994 (Leiden: Brill, 1997; 477p. \$105.00. Nag Hammadi and Manichaean Studies XXXII). This new work of 6,092 entries is arranged by broad topic with books and their reviews listed followed by articles. The author index with cross-references throughout the text refer to citations in only this volume.

For the purposes of this bibliography by Elisabeth Arweck and Peter B. Clarke, New Religious Movements in Western Europe (Westport, Conn.: Greenwood, 1997; 380p. \$89.50. Bibliographies and Indexes in Religious Studies, 41) religious "groups that have formed since World War II are considered new religious movements" (Pref.). Based on the collection at the Centre for New Religions at King's College, London, the 1,877 often annotated entries are arranged by main entry, usually author or editor, followed by indexes for period, movement, personal name, and subject. The index is to the page, not the citation number. This volume extends the coverage of the movements in earlier bibliographies such as Diane Choquette, New Religious Movements in the United States and Canada (BC28) and Harold W. Turner, Bibliography of New Religious Movements in Primal Societies (BC19) to Western European researchers and observers. 
Both of Omnigraphic's holiday volumes have been updated for new editions. Holidays, Festivals, and Celebrations of the World Dictionary; Detailing More Than 1,400 Observances from All 50 States and More Than 100 Nations, edited by Helene Henderson and Sue Ellen Thompson (Detroit: Omnigraphics, 1997; xlvii, 822p. \$84.00; 1st ed. 1994 edited by Sue Ellen Thompson and Barbara W. Carlson) adds 500 new entries for primarily state, national, and legal holidays, along with a new section on the Millennium. The subject index is much expanded; relevant Web sites are listed. Religious Holidays and Calendars: An Encyclopedic Handbook, edited by Karen Bellenir (Detroit: Omnigraphics, c 1998, 1997; 316p. \$70.00; 1st ed. 1993 edited by Alan Kelly) also offers an annotated listing of Web sites. The presentation is now chronological according to a specific religious calendar. Of the 450 entries, 200 are new.

Emily Post's Etiquette is alive and well in this 16th edition, edited by Peggy Post (New York: Harper/Collins, 1997; 845p. \$85.00; 15th ed. 1992. AL156). Recognizing that the "practice of manners is ever changing" (Introd.) this edition is much updated with sections on such topics as sexual harassment (within the section On the Job), electronic communication (under Correspondence), caller ID and voice mail (under On the telephone). This, the seventy-fifth anniversary of the first edition (1922), points up the continued interest in manners.

A companion to the Index to Book Reviews in England 1749-1774 (BE744) extends the coverage in the Index to Book Reviews in England 1775-1800 by Antonia Forster (London: British Library, 1997; 490 p. £85) for reviews of 4,981 titles of poetry, fiction, and drama. Under author, a full bibliographical citation is given which can include complete title, size, pagination, publisher/printer/bookseller, one location, and, of course, where reviewed. Not indexed.
Coverage of the eighteenth century in the Index of English Literary Manuscripts, vol. 3: 1700-1800, is now complete with part 4: Laurence Sterne-Edward Young (London: Mansell, 1997; 646p. £135). This volume "also includes the final cumulative first-line index of all the verse which is described in the manuscript entries or mentioned in the Introduction to parts 14 of volume III" (Pref.).

Several bibliographies of post-colonial literature in English have already appeared: Australia, 1970-1992 by Richard Lever, James Wieland, and Scott Findlay (New York: G. K. Hall, 1996; xxx, 361p.) and Southeast Asia, New Zealand and the Pacific, 1970-1992 by Mark Williams (New York: G. K.Hall, 1996; xxii, 370p.). Now Post-Colonial Literature in English: General, Theoretical, and Comparative 1970-1993 by Alan Lawson et al. (New York: G. K. Hall, 1997; xxiii, 374p. \$65) provides references to the underpinnings for the study of this genre through a bibliography of 1,315 annotated entries for books, dissertations, chapters and essays, and periodical articles all arranged in one alphabetical sequence. The topical index is very useful. The earlier works are arranged by authors and genres with author and subject indexes. All have very interesting introductory essays surveying scholarship on the topic.

For Australian literature, the ALS Guide to Australian Writers: A Bibliography 19631995, edited by Martin Duwell, Marianne Ehrhardt, and Carol Hetherington (St Lucia, Qld, Australia: Univ. Queensland Pr., 1997; 489p. \$19.95; 1st ed., 1992. BE847n) cites, by literary author, the major collections, fiction, nonfiction, and critical material. The new material incorporates citations from the "Annual Bibliographies of Australian Literature" 19921996, which appeared in Australian Literary Studies (BE847).

The Oxford Companion to German Literature is now in a third edition, edited by Mary Garland (1997; 951p. \$75; 1st ed. 1976; 2nd ed. 1986. BE1244). The basic aim 
continues to be "to represent the multifaceted history and cultural spectrum of Central Europe's past and present German-speaking countries and communities" (Pref.). This edition revises the coverage to include much new twentieth-century material as well as literary life in major cities in this German-speaking world (e.g., Basel). Henry Burnand Garland, who compiled both earlier editions, died and his wife Mary Garland, who had helped with the second edition, took over the major work of revision for the third edition. She died while this edition was in press. Tribute must be paid to both husband and wife for a job well done.

For Spanish literature, a new edition and a supplement have appeared. Hensley C. Woodbridge has updated his Guide to Reference Works for the Study of Spanish Languages and Literature and Spanish American Literature (New York: Modern Language Association, 1997; 236p. \$37.50, \$18.00 paper; 1st ed. 1987. BE1430) to include 1994-1995 titles. The arrangement is very detailed so one must use the table of contents. The other volume, Catalogo bibliografico de la literatura picaresca siglos XVI-XX, by Joseph L. Laurenti (Kassel: Reichenberger, 1988; 605p. 75DM) adds publications from about 1991 to 1994-1995 in a supplement (1997; 155p. Teatro del Siglo de Oro. Bibliografias y catalogos, 18), the order following the order of the original.

Eighteenth-Century Spanish Chapbooks in the British Library: A Descriptive Catalogue, compiled by H. G. Whitehead (London: British Library, 1997; 145p. 30p. plates ) is a supplement to the author's Short-Title Catalogues of Eighteenth-Century Spanish Books in the British Library (1994; 3 vols.) and covers 300 products of the popular press, quartos and single sheets, the majority of which are anonymous. Mostly a title listing with index entries for names as subject, printer/booksellers, place of publication, first lines..

More Opening Nights on Broadway: A Critical Quotebook of the Musical Theatre,
1965 through 1981, compiled by Steven Suskin (New York: Schirmer; London: Prentice-Hall, 1997; 1141p. \$39) is a companion to Suskin's Opening Night on Broadway: A Critical Quotebook of the Golden Era of the Musical Theatre, Oklahoma! (1943) to Fiddler on the Roof (1964) (New York: Schirmer, 1990; 810p.) The dictionary gives for each of about 200 musicals the date of opening, name of the theater, cast list, a reproduction of some of the artwork used in the advertisements, and "excerpts selected from more than 1500 reviews" (p. 19). The arrangement is alphabetical with a chronological list, an index by name and title, and up-to-date brief biographies of major theater people and critics of the period. The opening essay on major developments in the musical theater gives such tables as top ticket prices (1943: Oklahoma at $\$ 4.40$; 1994: Show Boat revival \$75).

Phyllis Rauch Klotman compiled Frame by Frame: A Black Filmography in 1979 (BH227) to provide information on films "with Black themes or subject matter ... [or which] have substantial participation by Blacks as writers, actors, producers, directors, musicians, animators, or consultants, and films in which Blacks appeared in ancillary or walk-on roles" (p. xiii). Frame by Frame II by Phyllis Klotman and Gloria J. Gibson (Bloomington: Indiana Univ. Pr., 1997;771 p. \$49.95) extends the coverage to films and videos of 1978-1994, with a few TV features and documentaries. The index is extensive for names but still no subjects. The volume ends with a list of African American Oscar award winners and nominees.

Much has changed since the publication of the first edition of the Complete Film Dictionary by Ira Konigsberg (New York: Penguin Reference, 1997; 469p. \$34.95; 1st ed. 1987. BH258) due especially to the exploding world of technology and the influence of business and the marketplace "on virtually everything that transpires in the industry, including what we see and hear in the theater" (Pref.). The edi- 
tion covers from "A and B Printing" to "Zoptic Front Projection" in about 4,000 entries and 260 line drawings and photographs as it seeks to be a "major sourcebook: for the language of filmmaking and film studies."

Aside from a change in title, a slightly smaller format, and a few editorial corrections, Planet Earth Macmillan World Atlas (New York: Macmillan, 1997; 415p. \$39.95) is a verbatim reissue of the 1996 Macmillan World Atlas. The maps and illustrations are exactly the same whereas the text differs only in the inclusion of the names of six countries in the selected resources list not in the 1996 edition. The publisher makes no attempt to note any connection between the two volumes. The only major distinction between this atlas and the Macmillan World Atlas, aside from the title, is the size. The 1996 atlas measures 14 inches $(36 \mathrm{~cm})$ high by 10 inches wide, whereas the Planet Earth Atlas is only 12 inches $(31 \mathrm{~cm})$ by 9 inches. The 1996 atlas, which is now out of print, was favorably reviewed so although it would be redundant to own both volumes, it is certainly worthwhile to own one of them.-A. M.

Gorton Carruth has updated The Encyclopedia of American Facts and Dates (10th ed. New York: HarperCollins, 1997;1096p. $\$ 45)$ through 1996. The ninth edition (1994; DB58) carried information up to November 1,1992 . For this edition, the index has been expanded and the yearly introductions or summaries have been extended back in time.

Supplement 1, Abbe, Robert-Alexander, Robert Evans, of Encyclopedia USA, edited by Donald W. Whisenhunt (Gulf Breeze, Fla.: Academic International, 1997; 248p. DB47) treats material that missed the deadline and new entries, usually for newly deceased people. The publisher states that supplements will continue as will ten-volume indexes.

Pre-Columbian Contact with the Americas across the Oceans: An Annotated Bibliography by John L. Sorenson and Martin H. Raish (2d. ed. Provo, Utah: F.A.R.M.S.,
1996. 2 vols. $\$ 89.00$; 1st ed. 1990. DB22) is available in paper and CD-ROM. Comprising "over 5,100 citations, plus several hundred other references to reprints, new editions, translations and reviews contained within the main entries" (Introd.), the annotated bibliography is interdisciplinary and eclectic. The editors do not even shy away from some diffusionists of ill repute in professional circles when their works serve the purpose of stirring up discussion and encouraging innovative research. The volumes are arranged by main entry with a detailed subject index. The computerized version keeps much of the booklike presentation; it is actually possible to browse through the book from the preface to the last item in the $\mathrm{Z}$ section. When one searches, the search engine marks the keyword(s) or phrase and one hops from one retrieved citation to another by using the previous and next icons. In between, one can stop to see other citations by the same author which may not contain the search terms. The computer program allows custom output, and the viewing screen also acts as a word processor, offering considerable editing capabilities. The computerization of the bibliography facilitates not only easier searching than the printed version but also the compilation of a customized, personal bibliography. Those libraries that find the print version valuable will want to make the computerized version readily available.-J. S.

For Canadian Reference Sources: An Annotated Bibliography: General Reference Works, History, Humanities (Vancouver, BC: UBC Pr., 1996; 1076p. \$225: 2nd ed. by Dorothy E. Ryder. 1981. AA456n), compilers Mary E. Bond and Martine M. Caron cite, in 4,194 annotated entries, "reference sources of all types about Canada, Canadian and foreign publications which describe Canadian people, institutions, organizations, publications, art, literature, languages, history" (Introd.). The volume is bilingual for the headings, annotations, and subject index. 
Hans Zell and Cecile Lomer, compilers of the African Studies Companion: A Resource Guide \& Directory (London, New Providence, N.J.: H. Zell, 1997; 276p. $\$ 75.00 ; 1$ st ed. 1989; DD55), seek to "provide within the covers of a single compact volume quick and easy access to a wide range of information in the African studies field. ... [The] revisions and updates for the new edition have been quite substantial" (Pref.), growing from 667 to 935 entries. The bibliography and directory cover reference works, journals, major documentation centers and libraries (even including their Web and e-mail addresses), publishers, dealers and distributors, organizations, associations, foundations, awards and prizes, abbreviations, and acronyms.

Recognizing the substantial monographic literature in the evaluation of staff training programs, Jack J. Phillips has revised and updated the earlier chapters as well as added seven new chapters to the Handbook of Training Evaluation and Measurement Methods (Houston: Gulf Publ, 1997; 420p. \$55; 1st ed. 1983). The twenty chapters focus on the need for evaluation within the overall human resource development function, the presentation of models and design issues, a discussion of data collection and analysis, and issues related to implementation. The goal of the book is to show users how to achieve a variety of evaluation and measurement results, for example, converting data to monetary values, selecting the optimum evaluation strategy, determining costs of programs, calculating return on investment for programs, and designing instruments for use in evaluation and the measurement of training programs.- J. C. 